\title{
DEVELOPMENT OF HIGHER ORDER THINKING SKILL-BASED QUESTIONS ON STUDENTS' CREATIVE THINKING ABILITY
}

\author{
Evi Fauziah*, Mudmainah Vitasari, and Lulu Tunjung Biru \\ Natural Science Education Study Program, Faculty of Teacher Training and Education, Sultan Ageng Tirtayasa \\ University, Banten, Indonesia \\ *Email: evifauziah268@gmail.com
}

Acceped: August 23 2021. Approved: Sept 01 2021. Published: Nov 082021

\begin{abstract}
The study aims to develop valid higher-order thinking skill-based questions on the water and life topics for measuring junior high school students' creative thinking ability. The Borg and Gall development model was applied in this study. The development steps were limited to the fifth step, including identifying potential and problems, collecting data, designing the product, validating the design, and revising the design. The instrument used is a logical validation questionnaire that utilizes a Likert scale to ascertain the validity of the questions based on expert judgment and their reliability scores. The development of higher-order thinking skill-based questions on Junior High School students shows that the developed product is valid. It is based on expert validity assessments conducted by material, evaluation, and educator experts. A total of 27 questions were tested, and the average validity score of $77 \%, 80 \%$, and $84 \%$ from the material, evaluation, educator expert assessments, respectively. In conclusion, all 27 questions developed are valid, with an overall average validation score of $80 \%$ and a reliability score of $83.7 \%$ in the very reliable category.
\end{abstract}

Keywords: Development Research, Higher Order Thinking Skill, Creative Thinking Ability, Water and Life

\section{INTRODUCTION}

The ability to think creatively is one of the skills that students need to keep up with the times, especially in the twenty-first century. The complexity of problems in all aspects of modern life and the competitive level [1] is increasing in the twenty-first century. Hence, the ability to think creatively should be nurtured from a young age in the hopes of using it to solve problems later in life.

Creative thinking is expected to help students develop independent personalities, manage their learning process, and construct their knowledge, especially in the learning process. In facing today's challenge, junior high school students are required to think logically, analytically, systematically, critically, creatively, and cooperatively [2]. So, if students were previously considered sufficient to know, understand, and apply, in the twenty-first century, additional abilities are required, one of which is the ability to think creatively.

However, students' creative thinking abilities are still low [3,] under-empowered and not fully developed [4]. Furthermore, the researchers discovered that students have a low creative thinking ability based on the findings of field observations conducted at State Junior High School 1 Pabuaran, where it was found that students' creative thinking abilities are still relatively low.

Students are less motivated to improve their creative thinking skills during the learning process, so changes are required to address these issues. However, overcoming these issues and developing creative thinking abilities is complex and requires training. One of the methods for developing students' creative thinking abilities is to get them used to work on questions that train these skills [5].

If students are expected to think creatively, the assessment given must measure that ability as well. Specific questions that require in-depth analysis and evaluation are used in the assessment that can measure a person's creative thinking ability. In contrast, the questions that need analysis and evaluation are Higher Order Thinking Skillsbased questions.

The creative thinking ability can be measured by higher-order thinking skills, with the study's findings indicating that students' creative thinking abilities differ when solving higher-order questions [6]. Therefore, the researcher can conclude that higher-order thinking skills-based questions can assess students' creative thinking ability.

According to Bloom's taxonomy revised by Anderson and Krathwohl [7], the dimensions of the thinking process are divided into Low Order Thinking Skills (LOTS), Medium Order Thinking Skills (MOTS), and Higher Order Thinking Skills (HOTS). Whereas LOTS refers to the ability to know and understand, MOTS is the ability to apply, and HOTS is the ability to analyze, evaluate, and create. In addition to Anderson and Krathwohl, Istiyono states that higher-order thinking skills include analyzing, evaluating, and creating [8].

However, it has been discovered that the assessment questions have not been oriented to higher-order thinking skills (HOTS). It is in line with the findings of the previous study. The 
questions used to assess student learning outcomes in schools are not yet oriented to higher-order thinking skills (HOTS) but instead, measure low-level thinking skills (LOTS) [9].

Secondly, according to Yuliandini, N. et al. [10], the teacher did not develop questions based on higher-order thinking skills. In referencing the two studies, the researchers conducted interviews with science teachers at State Junior High School 1 Pabuaran. The interview results revealed that the teachers at the school had implemented questions based on higher-order thinking skills, though not all of the questions were related to higher-order thinking skills.

It happens because developing higher-order thinking skills (HOTS) questions is not easy work. In addition, the lack of information on questions of higher-order thinking skills is also one of the reasons for this. Thus, it is necessary to develop questions based on higher-order thinking skills (HOTS) that can be used to train students' creative thinking skills.

The theme of water and life contains the material chosen to develop higher-order thinking skill-based questions on creative thinking ability. Water and life is a learning theme consisting of several concepts taught in Science Subjects in the second semester of first-year students at Junior High School. The theme of water and life was chosen because it contains materials that are very familiar to students and frequently interact in everyday life, even if they are not always aware of it.

So, it would be better if to bring up students' creative thinking skills starting from something related to an actual situation first, namely a problem that students can encounter in the environment around where they live. The material contained in the water and life theme is also complex because the materials contained in the water and life theme are interconnected, so a thinking process is needed that is more than just memorizing to understand the concepts contained.

Based on the background described, the researchers are interested in conducting a study on the Development of Higher Order Thinking Skill-Based Questions on Junior High School Students.

\section{RESEARCH METHOD}

The Research and Development method is used to develop questions based on higher-order thinking skills. According to Sugiyono [11], the Research and Development method is a research method that is used to develop and test specific products. Sukmadinata [12] expressed a different viewpoint, claiming that $R \& D$ is a process or set of steps that can be tracked to develop a new product or improve an existing one.
The Borg and Gall development model [11] has ten steps: (1) potential and problems, (2) data collection, (3) product design, (4) design validation, (5) design revision, (6) product trials, (7) product revisions, (8) product trials, (9) product revisions, and (10) mass product manufacture. However, there were only five initial steps in this study's research and development process: (1) potential and problems, (2) data collection, (3) product design, (4) design validation, and (5) design revision. Without losing their essence, the research and development steps can be modified and simplified [13].

The process of systematically searching and compiling data obtained from interviews, field notes, and documentation is known as the data analysis technique [14]. The data analysis technique used in this study was to calculate the percentage score of the validator's validation and reliability assessment. The validator's assessment is summarized in a validation questionnaire sheet, which in this case will refer to the Likert scale as a positive statement with four rating scales, as shown in the table below:

Table 1 Validation sheet questionnaire score [15]

\begin{tabular}{cc}
\hline Answer options & Score \\
\hline Excellent (E) & 4 \\
Good (G) & 3 \\
Bad (B) & 2 \\
Poor (P) & 1 \\
\hline
\end{tabular}

The method of processing data from the validation results will be carried out using the following formula [15]:

$$
\text { Value }=\frac{\sum \text { Obtained score }}{\sum \text { Maximum score }} \times 100 \%
$$

A classification of the validation results will be carried out to interpret the value obtained from the expert validation based on the results of the above calculations. The reference criteria for question validation can be seen in the following table:

Table 2 Question validation criteria [16]

\begin{tabular}{cc}
\hline Value in percent & Validation category \\
\hline $81.26 \%-100 \%$ & Very Valid \\
$62.6 \%-81.25 \%$ & Valid \\
$43.8 \%-62.5 \%$ & Less Valid \\
$25 \%-43.7 \%$ & Invalid \\
\hline
\end{tabular}

Regarding the percentage agreement reliability test, the percentage agreement is a percentage of the suitability of the value between the first and the second appraisers on an 
instrument. The formula for calculating the percentage of agreement is as follows:

$$
R=\frac{\overline{d(A)}}{\overline{d(A)}+\overline{d(D)}}
$$

Note: $\mathbf{R}$ is the coefficient of reliability

$\overline{d(A)}$ is the average degree of appraisers agreement $\frac{d(D)}{d(D)}$ is the moderate degree of appraisers disagreement

The reliability coefficient is described as follows:

Table 3 Reliability Coefficient Interpretation [17]

\begin{tabular}{ll}
\hline Coefficient Interval & Category \\
\hline $0.00-0.19$ & Less reliable \\
$0.20-0.39$ & Somewhat reliable \\
$0.40-0.59$ & Quite reliable \\
$0.60-0.79$ & Reliable \\
$0.80-1.00$ & Very reliable \\
\hline
\end{tabular}

\section{RESULT AND DISCUSSION}

Development of Higher Order Thinking SkillBased Questions

This section explains how to develop higherorder thinking skill-based questions. The experts and educators validate before being turned into a final product in the form of higher-order thinking skillbased questions on Junior High School students' creative thinking ability with the theme of water and life.

\section{Potential and Problems}

The first step is to assess the possibilities and issues. At this point, the researcher has completed several critical tasks, including (1) conducting a literature review on creative thinking ability and higher-order thinking skills-based questions; the literature review results revealed that students' creative thinking skills remained low. Also, it hasn't been fully developed.

a. Problem Analysis

The problem analysis goal is to determine what problems exist in the area where the research is being conducted. The results of interviews with teachers discovered that students' thinking ability in terms of creative thinking is still relatively low, with only a few students able to think creatively while the majority has low, even poor, creative thinking ability.

Furthermore, the researchers discovered that the teacher was not optimal in developing higherorder thinking skill-based questions. However, higher-order thinking skill-based questions could be used to train students' abilities to become accustomed to higher-order thinking skill-based questions. Students' higher-order thinking skills can be honed by asking questions that encourage them to do so.

b. Student needs analysis

Problems that students can directly encounter can increase their motivation to solve them, especially if the problem impacts students so that questions about the surrounding environment and real-life situations that students frequently encounter around their homes can help them understand the material and understand the material improve their thinking skills. It is in line with Suparman \& Husen's [18] idea, which states that learning about real-world problems allows students to solve problems and determine solutions and encourages students to think creatively.

c. Curriculum analysis

The curriculum used in schools is determined through curriculum analysis. After deciding the curriculum used, the Competency Standards and Basic Competencies contained in the curriculum were reviewed. Then, the researchers determine an appropriate material to develop higher-order thinking skills-based questions.

\section{Data collection}

The data collected by the researchers were carried out in several stages as follows:

a.Literature review

The researcher used this literature review to find references related to the researcher's product.

b.Interview

Researchers conducted this interview to determine the potential and problems, student needs, school curriculum, and materials that are in line with the research that will be developed. The researcher then proceeded to take the following steps:

- The purpose of this interview was to determine the theme and Basic Competency of higherorder thinking skill-based questions on Junior High School students' creative thinking ability with the theme of water and life. Based on the findings of the analysis and interviews, the Basic Competency of Water and Life theme would be as listed in Table 3 as follows:

Table 4 Basic Competency

\begin{tabular}{ll}
\hline \multicolumn{2}{c}{ Basic Competency } \\
\hline 3.3 & $\begin{array}{l}\text { Explain the concept of mixtures and } \\
\text { single substances (elements and } \\
\text { compounds), physical and chemical } \\
\text { properties, physical and chemical } \\
\text { changes in everyday life }\end{array}$ \\
Analyze the interactions between living \\
things and their environment as well as
\end{tabular}


population dynamics due to these interactions

3.8 Analyze the occurrence of environmental pollution and its impact on the ecosystem

4.3 Presenting the results of investigations or works on the properties of solutions, physical and chemical changes, or the separation of mixtures

- Then, the researchers create question grids based on higher-order thinking skills on creative thinking ability, including Basic Competency, competency achievement indicators, aspects and indicators of creative thinking ability, question indicators, cognitive level, and the number of questions. The answer rubrics, alternative answers, and draft questions are all presented separately.

\section{Product Design}

At this stage, questions are developed based on the findings of the initial analysis. The questions are designed at this stage as a questions grid based on higher-order thinking skills. They are adapted to the needs of teachers, student characteristics, the curriculum used, and aspects and indicators of creative thinking ability, which in this case include four aspects and nine indicators of creative thinking ability. Table 4 shows the aspects and indicators of creative thinking ability used to develop the questions:

Table 5 Aspects and indicators of creative thinking [19]

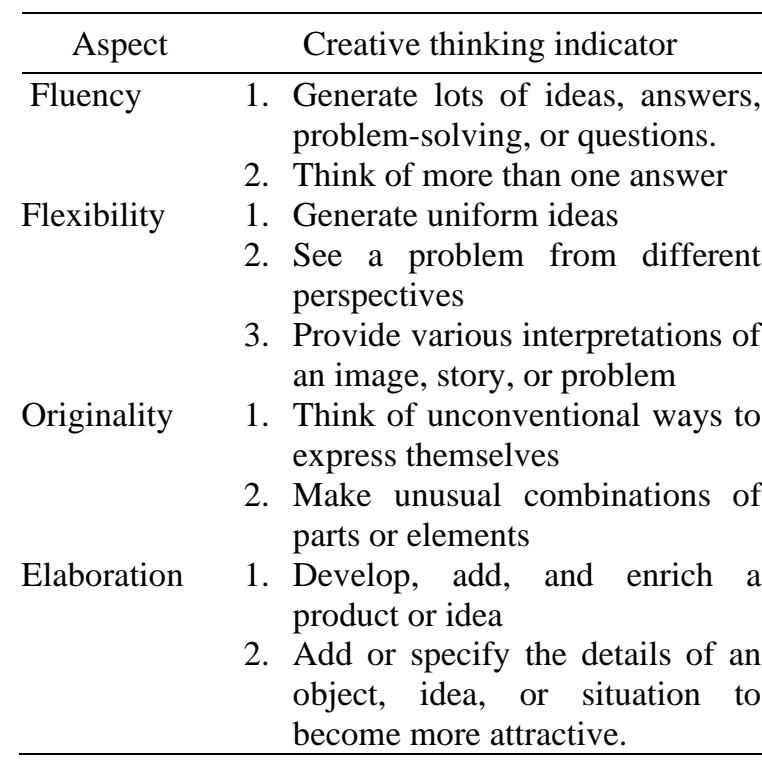

The design of questions developed by the researcher in this study was in the form of description questions, with 27 questions developed.

\section{Design validation}

This design validation stage aims to generate higher-order thinking skill-questions that experts and educators have validated. The type of validity that researchers use is logical validity. The term "logical validity" is defined as an instrument that is declared valid based on reasoning, which refers to expert and educator reasoning [20]. The results of product validation conducted by experts and educators are then interpreted using the assessment criteria proposed by Ain [16], including four assessment categories: invalid, less valid, valid, and very valid.

\section{Design Revision}

After the higher-order thinking skillbased questions were validated by experts (materials and evaluations) and educators, the design revision was carried out. Product revisions were according to the suggestions given. As for the suggestions given, material experts focus more on content; evaluation experts provide recommendations for improvement based on construction and language. At the same time, the educators state that the questions are good and follow students' conditions and the learning applied by teachers in schools. The suggestions for overall improvement can be seen in Table 7 .

\section{Product Validation Results of Higher Order Thinking Skill-Based Question}

Product validation was carried out by two expert lecturers, as material and evaluation experts and educators. The following is a list of additional explanations for the validation results:

\section{Validation of items by material experts}

Question validation by material expert validators includes six assessment indicators based on [21] with modifications: (1) the suitability of the questions with essential competencies, (2) the suitability of the questions with indicators of competency achievement, (3) the suitability of the questions with the subject matter, (4) the suitability of the questions with the level of higherorder thinking skill, and (5) the suitability of the questions with aspects and indicators of creative thinking.

Based on material experts' assessments of the assessment indicators, each item was valid, with an overall validation average score of $77 \%$. Among 27 questions developed, 6 of them are in the very valid category. The other 21 are in the valid category. When expressed as a percentage, $22 \%$ of the questions developed by the researcher were very valid, and $78 \%$ were invalid categories with a reliability value of 0.80 or $80 \%$ (reliable). Based on these findings, it is possible to conclude that the questions developed by the researcher are 
materially valid and can be used based on the criteria used as references.

\section{Item validation by evaluation expert validator}

The validation of the questions by this evaluation expert validator includes ten assessment indicators based on [21-23] with modifications consisting of (1) the suitability of questions with scoring guidelines, (2) the suitability of question words or commands that require description answers, (3) the suitability of the limits of answers and questions by indicators of creative thinking ability, (4) tables, pictures, cases, and the so on, as appropriate to the problem at hand. (5) the clarity of the questions' instructions, directions, or orders (6) the tables, pictures, and examples provided help clarify the questions' intent. (7) the clarity of font type and size, (8) the suitability of the language used with the Indonesian Spelling System, (9) the language used has no double meanings, and (10) the language used is simple to comprehend.

Based on the evaluation expert's assessment on the assessment indicators, each item was declared valid. The overall validation average score of $80 \%$, among the 27 questions developed, 8 questions in the very valid category and 19 questions in the very valid category, which, when expressed as a percentage, means that the questions developed by the researcher were $30 \%$ very valid and $70 \%$ valid with a reliability value of $85 \%$ or 0.85 , (very reliable). Based on these findings, it can be concluded that the 27 questions developed by the researcher are valid, meet the assessment criteria, and can be used in terms of construction and language.

\section{Validation of questions by educator}

Question validation by educators includes 9 assessment indicators, namely (1) Questions according to the level of student development, (2) Questions according to student needs, (3) Questions relevant to the material presented by the teacher in class, (4) Questions relevant to the learning objectives the teacher wants to achieve, (5) Clarity of instructions, directions, or orders in the questions (6) The teacher can use the questions as material to evaluate students' abilities, (7) The teacher can use the questions to determine the development of students' abilities, (8) The language used is easily understood, (9) The language used does not contain words that can offend students.

Based on the teacher's assessment of the indicators, each item is valid, with an overall validation average score of $84 \%$. Among 27 questions, 10 questions are in the very valid category, and 17 questions are in the valid category, which, when converted into a percentage, means that the questions developed by the researcher were $37 \%$ very valid and $63 \%$ valid with a reliability value of 0.86 or $86 \%$ (very reliable). Based on these findings, it can be concluded that the questions developed by the researchers are valid in terms of classroom learning activities and can be used.

The following summarizes the evaluations conducted by three validators (material expert, evaluation expert, and educator) for each item developed by the researcher.

Table 5 shows that the data obtained after the validation by the three validators. Each question developed by the researcher was either in the valid and very valid categories on average, with 8 items in the very valid category and 19 items in the valid category, which, when expressed as a percentage, means that $30 \%$ of the questions developed by the researcher were very valid and $70 \%$ were valid.

Figure 1 shows the overall summary of the average score of the three validators (material expert, evaluation expert, and educator) from higher-order thinking skill-based questions on Junior High School students' creative thinking ability in the theme of water and life.

Table 6 Recapitulation of the average score of each item by three validators

\begin{tabular}{cccccc}
\hline \multirow{2}{*}{$\begin{array}{c}\text { Question } \\
\text { number }\end{array}$} & \multicolumn{3}{c}{ Validator } & $\begin{array}{c}\text { Aver } \\
\text { age } \\
\text { score }\end{array}$ & Category \\
\hline 1 & ME & EE & E & \\
\hline 2 & $79 \%$ & $80 \%$ & $75 \%$ & $78 \%$ & Valid \\
3 & $75 \%$ & $78 \%$ & $75 \%$ & $76 \%$ & Valid \\
4 & $75 \%$ & $78 \%$ & $100 \%$ & $84 \%$ & Very Valid \\
5 & $67 \%$ & $73 \%$ & $100 \%$ & $80 \%$ & Valid \\
6 & $67 \%$ & $73 \%$ & $100 \%$ & $80 \%$ & Valid \\
7 & $83 \%$ & $85 \%$ & $75 \%$ & $81 \%$ & Valid \\
8 & $71 \%$ & $85 \%$ & $75 \%$ & $77 \%$ & Valid \\
9 & $79 \%$ & $80 \%$ & $75 \%$ & $78 \%$ & Valid \\
10 & $75 \%$ & $75 \%$ & $75 \%$ & $75 \%$ & Valid \\
11 & $79 \%$ & $85 \%$ & $75 \%$ & $80 \%$ & Valid \\
12 & $75 \%$ & $75 \%$ & $75 \%$ & $75 \%$ & Valid \\
13 & $79 \%$ & $80 \%$ & $75 \%$ & $78 \%$ & Valid \\
14 & $83 \%$ & $85 \%$ & $97 \%$ & $88 \%$ & Very Valid \\
15 & $79 \%$ & $78 \%$ & $89 \%$ & $82 \%$ & Very Valid \\
16 & $71 \%$ & $78 \%$ & $78 \%$ & $76 \%$ & Valid \\
17 & $83 \%$ & $83 \%$ & $100 \%$ & $89 \%$ & Very Valid \\
18 & $79 \%$ & $83 \%$ & $72 \%$ & $78 \%$ & Valid \\
19 & $83 \%$ & $85 \%$ & $75 \%$ & $81 \%$ & Valid \\
20 & $79 \%$ & $80 \%$ & $97 \%$ & $85 \%$ & Very Valid \\
21 & $75 \%$ & $78 \%$ & $78 \%$ & $77 \%$ & Valid \\
22 & $75 \%$ & $75 \%$ & $97 \%$ & $82 \%$ & Very Valid \\
23 & $79 \%$ & $80 \%$ & $100 \%$ & $86 \%$ & Very Valid \\
24 & $83 \%$ & $80 \%$ & $78 \%$ & $80 \%$ & Valid \\
25 & $79 \%$ & $78 \%$ & $75 \%$ & $77 \%$ & Valid \\
26 & $83 \%$ & $85 \%$ & $75 \%$ & $81 \%$ & Valid \\
27 & $75 \%$ & $78 \%$ & $75 \%$ & $76 \%$ & Valid \\
\hline
\end{tabular}

Note: $\mathrm{ME}=$ Material Expert, $\mathrm{EE}=$ Evaluation

Expert, $\mathrm{E}=$ Educator 


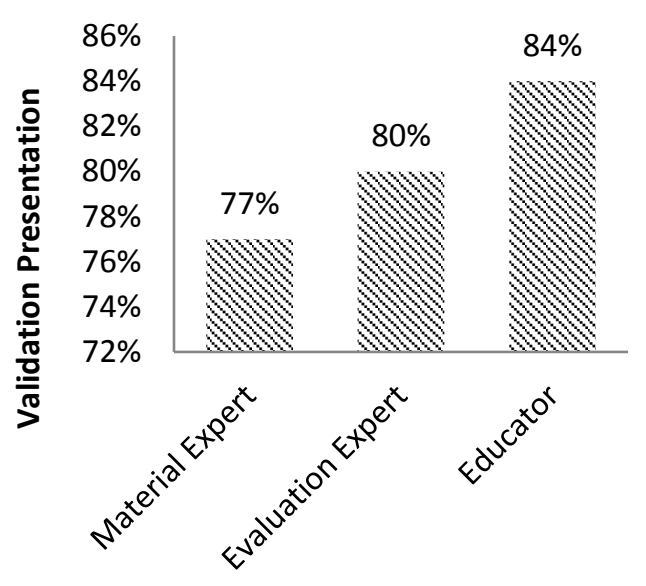

Figure 1 Overall validation score recapitulation

Figure 1 indicates that the overall average score of the validation is in the valid category with an $80 \%$ percentage. It means that higher-order thinking skill-based questions developed by the researchers are valid in terms of content, construction, and language and their applicability to the learning methods used by teachers in schools.

The validator makes constructive suggestions based on the results of the validation of higher-order thinking skill-based questions. Table 7 shows the validator's suggestions for higher-order thinking skill-based questions developed, as well as the results of the revisions that were implemented:

Table 7 Suggestions for improvement from the validator

\begin{tabular}{|c|c|c|}
\hline No & $\begin{array}{l}\text { Improvement } \\
\text { suggestions }\end{array}$ & $\begin{array}{l}\text { Revisions that have } \\
\text { been made }\end{array}$ \\
\hline 1 & $\begin{array}{l}\text { Watch for errors in } \\
\text { writing/typing }\end{array}$ & $\begin{array}{l}\text { Reread the questions } \\
\text { and correct typing } \\
\text { errors }\end{array}$ \\
\hline 2 & $\begin{array}{l}\text { Improve the } \\
\text { presentation of the } \\
\text { question grid }\end{array}$ & $\begin{array}{l}\text { Make improvements } \\
\text { according to expert } \\
\text { validator suggestions }\end{array}$ \\
\hline 3 & $\begin{array}{l}\text { Add image and } \\
\text { table sources }\end{array}$ & $\begin{array}{l}\text { Add the source of the } \\
\text { image in question no. } \\
22 \text { and source of } \\
\text { tables in questions } \\
\text { no. } 19 \text { and } 24\end{array}$ \\
\hline 4 & $\begin{array}{l}\text { Eliminate the words } \\
\text { above and below in } \\
\text { the command that } \\
\text { accompanies the } \\
\text { question }\end{array}$ & $\begin{array}{l}\text { Revise by directly } \\
\text { mentioning the } \\
\text { figure, table, and } \\
\text { statement in question }\end{array}$ \\
\hline 5 & $\begin{array}{lr}\text { Provide } & \text { keywords } \\
\text { in } & \text { alternative } \\
\text { answers } & \end{array}$ & $\begin{array}{l}\text { Improve according } \\
\text { to the validator's } \\
\text { suggestions }\end{array}$ \\
\hline
\end{tabular}

6

Improve the picture of question number 1

7 Improve alternative answer to question number 2

8

Add alternative answers to questions number 1 and 10

\section{CONCLUSION}

The higher-order thinking skill-based questions on the creative thinking ability of Junior High School students were successfully developed using the Borg and Gall development model. According to Sugiyono, Borg, and Gall's research and development has ten steps. However, the research and development steps used in this study were only limited to five: (1) potential and problems, (2) data collection, (3) product design, (4) design validation, and (5) design revision.

In terms of the development results of higher-order thinking skill-based questions, the average validity value is $80 \%$. Among 27 questions developed by the researcher: 8 of them fall into the very valid category, and the other 19 fall into the valid category, which, when expressed as a percentage, means that $30 \%$ of the questions developed by the researcher are categorized into the very valid category, and $70 \%$ are categorized into the valid category, with an average reliability value of $83.7 \%$ classified as very reliable.

\section{REFERENCES}

[1] Mursidik, E. M., Samsiyah, N., \& Rudyanto, H. E. (2005). Kemampuan Berpikir Kreatif dalam Memecahkan Masalah Matematika Open Ended Ditinjau dari Tingkat Kemampuan Matematika Pada Siswa Sekolah Dasar. Journal Pedagogia.

[2] Fajriah, N., \& Asiskawati, E. (2015). Kemampuan Berpikir Kreatif Siswa Dalam Pembelajaran Matematika Menggunakan Pendekatan Pendidikan Matematika Realistik Di SMP. Jurnal Pendidikan Matematika.

[3] Festiana, I. (2004). Modul Fisika Berbasis Masalah pada Materi Listrik Dinamis untuk Meningkatkan Kemampuan Berpikir Kreatif Siswa SMA. Jurnal Inkuiri.

[4] Susastra, I. (2007). Mengembangkan Kemampuan Berpikir Kreatif Melalui Pembelajaran Sains. Jurnal IKA (Ikatan Keluarga Alumni Universitas Pendidikan Ganesha).

[5] Kartini. (2012). Pengembangan Alat Ukur Berpikir Kritis Pada Konsep Senyawa 
Hidrokarbon untuk Siswa SMA di Kabupaten Kuningan . Jurnal Pendidikan MIPA.

[6] Suhandoyo, G., \& Wijayanti, P. (2016). Profil Kemampuan Berpikir Kreatif Siswa Dalam Menyelesaikan Soal Higher Order Thinking Ditinjau dari Adversity Quotient. Jurnal Ilmiah Pendidikan Matematika.

[7] Anderson, L. \&. (2010). Kerangka Landasan untuk Pembelajaran, Pengajaran, dan Asesmen Revisi Taksonomi Pendidikan Bloom. (Terjemahan). Yogyakarta: Pustaka Belajar.

[8] Istiyono. (2014). Pengembangan tes kemampuan berpikir tingkat tinggi fisiska (Pysthots) peserta didik SMA. Jurnal Penelitian dan Evaluasi Pendidikan.

[9] Netri, N., Holiwarni, B., \& Abdullah. (2018). Pengembangan Instrumen Tes Berbasis Higher order thinking skill (HOTS) Materi Kesetimbangan Kimia di kelas XI SMA/MA. JOM FKIP Volume 5 Edisi 2 Juli-Desember 2018.

[10] Yuliandini, N., Hamdu, G., \& Respati, R. (2019). Pengembangan Soal Tes Berbasis Higher OrderThinking Skill (HOTS) Taksonomi Bloom Revisi Sekolah Dasar. Jurnal Ilmiah Pendidikan Guru Sekolah Dasar.

[11] Sugiyono. (2010). Metode Penelitian Pendidikan (pendekatan kuantitatif, kualitatif, dan R\&D). Bandung: Alfabeta.

[12] Sukmadinata, N. (2015). Metode Penelitian Pendidikan. Bandung: PT. Remaja Rosdakarya.

[13] Sukmadinata, N. S. (2009). Metode Penelitian Pendidikan. Bandung: PT.Remaja Rosdakarya.

[14] Sugiyono. (2016). Metode Penelitian Kuantitatif, Kualitatif, dan $R \& D$. Bandung: Alfabeta.

[15]Riduwan. (2009). Dasar-dasar Statistika. Bandung: Alfabeta.

[16] Ain, T. N. (2013). Pemanfaatan Visualisasi Video Percobaan Gravity Current Untuk Meningkatkan Pemanfaatan Konsep Fisika Pada Materi Tekanan Hidrostatis. Jurnal Inovasi Pendidikan Fisika.

[17] Sujiyanto, A. E. (2009). Aplikasi statistik dengan SPSS 16.0. Jakarta: PT. Prestasi Pustaka Karya.

[18] Suparman \& Husen, D. (2015). Peningkatan Kemampuan Berpikir Kreatif Siswa Melalui Penerapan Model Problem Based Learning. BIOEDUKASI (Jurnal Pendidikan Biologi).

[19] Munandar, U. (2012). Pengembangan Kreativitas Anak Berbakat. Jakarta: Rineka Cipta.

[20] Riyani, R., Maizora, S., \& Hanifah. (2017). Uji Validitas Pengembangan Tes Untuk Mengukur Kemampuan Pemahaman Relasional Pada Materi Persamaan Kuadrat Siswa Kelas VIII SMP. Jurnal Penelitian Pembelajaran Matematika Sekolah.

[21] Riswanti, S., \& Idris, T. (2019). Pengembangan Rubrik Performance Assessment Berbasis
Keterampilan Proses . Biologi and Educational Journal (BaEj).

[22] Irawan, J., Hadi, S., Zulandri, Z., Jamaluddin, J., Syukur, A., \& Hadisaputra, S. (2021). Validating metacognitive awareness inventory (MAI) in chemistry learning for senior high school: A rasch model analysis. Jurnal Pijar Mipa, 16(4), 442-448.

[23] Jamaluddin, J., Jufri, A. W., Muhlis, M., \& Bachtiar, I. (2020). Pengembangan Instrumen Keterampilan Berpikir Kritis Pada Pembelajaran IPA di SMP. Jurnal Pijar Mipa, 15(1), 13-19. 